\title{
Implementation of Double-Duty Actions to Counter the Public Health Challenge of Double Malnutrition
}

\author{
Çift Kötü Beslenmenin Halk Sağlığına Meydan Okumasına Karşı Çift Görevli \\ Eylemlerin Uygulanması
}

\author{
Saurabh RamBihariLal Shrivastava*1, Prateek Saurabh Shrivastava ${ }^{2}$, Jegadeesh Ramasamy ${ }^{3}$
}

\begin{abstract}
Malnutrition has been observed in various forms ranging from under-nutrition to overweight and obesity. Even though, the overall estimates reflect a decline in the incidence of stunted children, the overall progress towards ending all forms of malnutrition is not on the right track. It is important to realize that a simultaneous rise in the incidence of both under-nutrition and overweight has been observed. This is predominantly because of the similar biological, environmental and socioeconomic factors that together contribute to the rise in the risk or prevalence of both forms of malnutrition. From a policy makers' perspective, the presence of a similar kind of factors which determine the incidence of both spectrums of malnutrition, implementation of integrated actions, policies and programs, can significantly deal with the global challenge of combating with all forms of malnutrition can be accomplished. To conclude, owing to the rising trend of the double malnutrition in different parts of the world, there is a great need to implement double-duty actions to respond to various forms of malnutrition.
\end{abstract}

Key words: Malnutrition, overweight, World Health Organization

\section{ÖZET}

Beslenme bozukluğu; yetersiz beslenmeden aşırı kilolu olmak ve obeziteye kadar çeşitli biçimlerde değişiklik olarak gözlenmektedir. Gelişim bozukluğu olan çocukların insidansında azalma tümsel olarak öngörülmesine karşın, tüm beslenme bozukluklarının sonlandırılmasındaki gelişme değerlendirildiğinde doğru yolda değildir. Hem yetersiz beslenme hem de aşırı kilolu olmanın eş zamanlı artışının gözlendiğinin, ayrımında olunması önemlidir. Bu durum ağırlıklı olarak, benzer biyolojik, çevresel ve sosyoekonomik etkenlerin hem risk artı̧̧ hem de her iki beslenme bozukluğunun prevelansının artışına katkı sağlamaktadır. Politikaları belirleyenler açısından, her iki beslenme bozukluğuna neden olan benzer etmenlerin varlığı, bütünleşmiş eylemlerin, politikaların ve programların uygulanması ile tüm kötü beslenme biçimleriyle küresel anlamda meydan okuma olan savaşın başarıyla tamamlanmasında anlamlı olabilir. Sonuç olarak, dünyanın farklı yerlerinde çifte beslenme bozukluğunun artış eğiliminde olması, çeşitli beslenme bozukluğu biçimlerine çifte-görev eylemlerle yanıt verilmesinin büyük oranda gerekliliğini göstermektedir.

Anahtar kelimeler: Kötü Beslenme, aşırı kilolu, Dünya Sağlık Örgütü

Received / Geliş tarihi: 29.05.2017, Accepted / Kabul tarihi: 23.07.2017

${ }^{1}$ Department of Community Medicine, Shri Sathya Sai Medical College \& Research Institute, Kancheepuram.

*Address for Correspondence / Yazışma Adresi: Saurabh RamBihariLal Shrivastava Department of Community Medicine, Shri Sathya Sai Medical College \& Research Institute, Kancheepuram (drshrishri2008@gmail.com)

Shrivastava SR, Shrivastava PS, Ramasamy J. Implementation of Double-Duty Actions to Counter the Public Health Challenge of Double Malnutrition. TJFMPC, 2017;11(3): 142_143.

DOI: $10.21763 /$ tjfmpc.336130 


\section{Dear Editor}

Malnutrition has been observed in various forms ranging from under-nutrition (wasting or stunting) to overweight and obesity. ${ }^{1}$ In case of under-nutrition, due to the insufficient intake of essential nutrients, a significant decline in the immune status and impairment in the brain development has been observed, which further predisposes individuals to infections, anemia and even blindness. ${ }^{1,2}$ On the other hand, due to the excess intake of fat, sugar or salts, a proportional rise in the incidence of non-communicable diseases has been observed. ${ }^{2}$

Even though, the global estimates reflect a decline of 43 million in under-five children who are stunted since the estimates recorded in 2000, the overall progress towards ending all forms of malnutrition is not on the right track in most of the nations across the world. ${ }^{2}$ Further, it has been estimated that close to 2 billion adults and 40 million under-five children are overweight and that non-communicable diseases are one of the commonest causes of deaths observed worldwide. ${ }^{2}$ Thus, it is quite clear that the world is facing the challenge of double burden of malnutrition, with $44.2 \%$ of the nations in the year 2016 having a $20 \%$ prevalence of stunting or anaemia and $35 \%$ prevalence of high body mass index in their settings. ${ }^{2}$

It is important to realize that a simultaneous rise in the incidence of both under-nutrition and overweight has been observed, as proven by the high propensity of a stunted child to become obese, when compared with normal child. ${ }^{2,3}$ This is predominantly because of the similar biological (such as poor adolescent and maternal nutrition prior to and during pregnancy, and nutrition status during the initial thousand days of life), environmental (like lack of nutritious \& healthy foods, and limited access to affordable and quality-assured health care services or improved water and sanitation services) and socioeconomic factors (viz. poverty, low socioeconomic status, educational status, etc.), that together contribute to the rise in the risk or prevalence of both forms of malnutrition. ${ }^{1-4}$

From a policy makers' perspective, the presence of a similar kind of factor which determine the incidence of both spectrums of malnutrition, implementation of integrated actions, policies and programs, can significantly deal with the global challenge of combating with all forms of malnutrition can be accomplished. ${ }^{2-4}$ The World Health Organization envisages for augmenting the efficiency of nutrition actions by means of a double-duty approach, but then it is extremely important to ensure that any of the current approaches or policies to deal with some form of malnutrition should not accidentally enhance the risk of other forms of malnutrition. ${ }^{3}$ In addition, there is an immense need to ensure that the ongoing interventions should concurrently reduce prevalence of other types of malnutrition. ${ }^{3}$ Further, newer strategies should be identified and implemented to minimize all forms of malnutrition by targeting the predisposing factors. ${ }^{2,3}$

To conclude, owing to the rising trend of the double malnutrition in different parts of the world, there is a great need to implement double-duty actions to respond to various forms of malnutrition.

\section{REFERENCES}

1. Shrivastava SR, Shrivastava PS, Ramasamy J. Childhood malnutrition: Where does the world stand? What else is needed? Int $\mathbf{J}$ Prev Med. 2016;7(2):36.

2. World Health Organization. Double-duty actions for nutrition: policy brief. Geneva: WHO press; 2017. p. 1-9.

3. Branca F, Demaio AR, Hawkes C. Double-duty actions for ending malnutrition within a decade; 2017.

http://who.int/mediacentre/commentaries/actions -ending-malnutrition/en/ [Access date: May 22, 2017].

4. Shrivastava SR, Shrivastava PS, Ramasamy J. Formulating a comprehensive strategy to counter the menace of malnutrition in developing countries. Arch Med Health Sci. 2014;2(2):266-8 